\title{
Predicting Juvenile Delinquency: The Nexus Of Childhood Maltreatment, Depression And Bipolar Disorder
}

Christopher A. Mallett

Cleveland State University, c.a.mallett@csuohio.edu

Patricia A. Stoddard Dare

Cleveland State University, p.stoddarddare@csuohio.edu

Mamadou M. Seck

Cleveland State University, m.seck@csuohio.edu

Follow this and additional works at: https://engagedscholarship.csuohio.edu/clsowo_facpub

Part of the Psychiatric and Mental Health Commons, Social Control, Law, Crime, and Deviance Commons, and the Social Work Commons

How does access to this work benefit you? Let us know!

\section{Publisher's Statement}

(c)2009 Wiley-Blackwell

\section{Recommended Citation}

Mallett, Christopher A.; Stoddard Dare, Patricia A.; and Seck, Mamadou M., "Predicting Juvenile Delinquency: The Nexus Of Childhood Maltreatment, Depression And Bipolar Disorder" (2009). Social Work Faculty Publications. 7.

https://engagedscholarship.csuohio.edu/clsowo_facpub/7

This Article is brought to you for free and open access by the School of Social Work at EngagedScholarship@CSU. It has been accepted for inclusion in Social Work Faculty Publications by an authorized administrator of EngagedScholarship@CSU. For more information, please contact library.es@csuohio.edu. 


\section{Predicting juvenile delinquency: The nexus of childhood maltreatment, depression and bipolar disorder}

CHRISTOPHER A. MALLETT, PATRICIA STODDARD DARE AND MAMADOU M. SECK, School of Social Work, Cleveland State University, Cleveland, OH, USA

\section{ABSTRACT}

Background It is important to identify and provide preventative interventions for youth who are most at risk for offending behaviour, but the connection between early childhood or adolescent experiences and later delinquency adjudication is complicated.

Aim To test for associations between specified mental disorders or maltreatment and later delinquency adjudication.

Method Participants were a random sample of youth before the juvenile courts in two Northeast Ohio counties in the USA $(n=555)$ over a 4-year time frame (2003 to 2006).

Results Logistic regression analysis identified a lifetime diagnosis of depression and/or bipolar disorder to be predictive of later youth delinquency adjudication, but found that childhood maltreatment (or involvement with the child welfare system) made delinquency outcomes less likely.

Implications Study implications are discussed as they relate to professionals working in the fields of child welfare, social work, mental health and juvenile justice. Awareness of risks associated with maltreatment may have led to effective interventions, while there may be less awareness of risks from depression in young people; however, studies tend not to take account of intervention variables. Copyright (C) 2009 John Wiley $\mathcal{E}$ Sons, Ltd.

\section{Introduction}

Identifying childhood, youth and family risk factors is vital in the prevention of juvenile offending behaviour and juvenile court involvement. Indeed, 
determining which specific risks, or combination of risks, impact on later offending and/or delinquent youth outcomes allows practitioners to identify most efficiently which of these children and youth are most at-risk (Farrington, 2005; Lay et al., 2005) and thus to target prevention and treatment more effectively.

\section{Juvenile delinquency and risk factors}

The juvenile courts' dual duty of community safety and youth rehabilitation has been a challenge for decades (Roberts, 2004). About 76\% of all cases coming before the juvenile courts in the USA are 'adjudicated delinquent' (Stahl et al., 2007). Definitions may vary in detail between states, but the essence is similar between the Ohio definitions and other states. In Ohio, anyone of the age of 17 or under 'who violates any law of the state, of the United States, or any ordinance or regulation of a political subdivision of the state, which would be a crime if committed by an adult, and who violates any lawful order of the court' may be adjudicated delinquent (Ohio revised code $\$ 2151.02$ ). Of the 1,660,700 youth adjudicated delinquent in the USA in 2004 (Stahl et al., 2007), a total of 350,000 were held in 591 detention centers (Sickmund et al., 2004; Holman and Ziedenberg, 2006), and 102,300 were held in 2964 correctional facilities (Snyder and Sickmund, 1999; Davis et al., 2008). Both detention centres (county) and correctional facilities (state) are run by the youth criminal justice system (there are no federal facilities for juvenile offenders in the USA). Most youths in state facilities have also been held in detention centres, though they tend to be more chronic, serious offenders. Every day, an average of 54,500 youths are incarcerated in US detention or correctional institutions (Office of Juvenile Justice and Delinquency Prevention, 2003; Sickmund, et al., 2004). These incarcerations may harm the youths and make it more likely they will continue offending (Benda and Tollet, 1999; Torres and Ooyen, 2002; Holman and Ziedenberg, 2006). It is important, where possible, to intervene with youth and families prior to detention or incarceration (Roberts, 2004).

No single factor is responsible for juvenile offending and subsequent incarcerations (Widom, 1991; Preski and Shelton, 2001; Turner et al., 2007; Maas et al., 2008); minority race (Poe-Yamagata and Jones, 2000), early childhood behaviour problems (Howing et al., 1990; Buka and Earls, 1993; Shader, 2003) and poor family functioning (Widom, 1991; Shader, 2003) have all been implicated.

\section{Maltreatment to delinquency link}

Risk factors in these circumstances tend to be cumulative and to have interactive effects, making delinquency prediction challenging for practitioners (Lemmon, 2006; Ford et al., 2007). A history of maltreatment has been shown to be significant even in the presence of these other risk factors (Smith and Thornberry, 1995; Maxfield and Widom, 1996; Lemmon, 1999; Wiebush et al., 2000), although most studies have documented a general link, and studies investigating an asso- 
ciation between types of maltreatment individually (physical abuse, sexual abuse and neglect) and delinquency have been limited (Currie and Tekin, 2006; Mersky and Reynolds, 2007). That this would be worth doing is suggested by the findings of Widom and Maxfield (2001), Egeland et al. (2002) and Fagan (2005), which showed that physical abuse and neglect victims have an elevated risk for later delinquency, but victims of sexual abuse do not. In the USA, maltreated children constitute between 40 per cent and 60 per cent of the 1.6 million youth adjudicated delinquent annually (Smith and Thornberry, 1995; Loeber and Farrington, 2001; Preski and Shelton, 2001; Currie and Tekin, 2006; Stahl, 2006; Crooks et al., 2007; Ford et al., 2007). These young offenders pose a substantial challenge to child welfare and social work agencies as well as juvenile courts.

\section{Adolescent mental health disorders to delinquency link}

In any given year in the USA, 5-10\% of youth have a serious emotional disturbance that causes substantial impairment in functioning at home, school or in the community (New Freedom Commission on Mental Health, 2003); another 4-8\% have a significant functional impairment (Center for Mental Health Services, 2004; Substance Abuse and Mental Health Services Administration, Office of Applied Statistics, 2004); half drop out of high school, and many have difficulty accessing mental health services (U.S. Department of Education, Office of Special Education Programs, 2001; Simpson et al., 2005; Bazelon Center for Mental Health, 2007). They are disproportionately from minority groups. Approximately 20 per cent of the US general population experience depression before adulthood, with five per cent of the youth population experiencing depression at any given time and another two per cent experiencing dysthymia - a depression that is less severe but lasts for a longer duration of time (National Institute of Mental Health, 2004). In Europe, prevalence rates are similar with four per cent of 12-17-year-olds and nine per cent of 18-year-olds diagnosed with depression (World Health Organization, 2005). Depression in young people is a significant public health problem, and often co-morbid with other mental health problems, including bipolar disorder (Gellerman et al., 2001; National Institute of Mental Health, 2006). One study revealed a 40-fold increase in bipolar disorder among youth over the last 10 years (National Institute of Mental Health, 2007).

There is growing evidence that these difficulties in young people are independently linked to later offending behaviour and youth delinquency, although the nature of the link is less clear (Moffitt, 1993; Heilbrun et al., 2005; Grisso, 2008). Aggressive behaviours before age 13 have been found to be predictive of delinquency and are often diagnosed as conduct or oppositional defiant disorders (Kashani et al., 1999; Tremblay and LeMarquand, 2001). Hyperactivity and attention problems seem to be linked to later risk taking and violent offending behaviours (Hawkins et al., 1998; Kashani et al., 1999). Delinquency and childhood 
depression are associated with physical aggression and stealing (Loeber and Kenan, 1994; Takeda, 2000; Moffitt and Scott, 2008). A direct link between mental disorders and youth violence or crime is more clearly established. In a large sample of youths in residential welfare care, those with co-morbid mental disorders were found most dangerous (Lyons and Schafer, 2000). In a large national study, others also found co-occurrence of emotional disturbance and delinquency in adolescence and young adulthood, recommending early prevention efforts (Overbeek et al., 2001).

It is not surprising, therefore, that it has been found that a substantial proportion of juvenile delinquent populations have been found to have mental disorder, 40-70\% among incarcerated youths (Burrell and Warboys, 2000; Lexcon and Redding, 2000; Huizinga et al., 2000; Teplin et al., 2002; Wasserman et al., 2002; Fazel et al., 2008). Within these populations, between 15 and 20\% have been diagnosed with either depression or dysthymia - making it the most prevalent diagnosis (Weiss and Garber, 2003), 13-30\% have been diagnosed with attention-deficit hyperactivity disorder (ADD)/attention deficit disorder and 3-7\% with bipolar disorder (Teplin et al., 2002, 2006; Goldstein et al., 2005; Mallett, 2008).

We sought to identify which early childhood illness or maltreatment factors are independently predictive of later youth delinquency adjudication. A unique feature of our study is the evaluation of the cumulative risk of these factors.

\section{Methods}

\section{Design}

This retrospective study utilised youth and family records tracked over 4 years. These anonymised records were provided explicitly for the research by two county juvenile courts in Northeast Ohio (Cuyahoga and Lorain) - in collaboration with each county's mental health boards and child welfare departments. Three principal variables were measured, based on identification of delinquency risk factors from the published literature, as discussed previously, and according to availability. These were two mental disorder variables: all types of depression and ADHD, and an overarching variable of childhood maltreatment.

\section{The sample}

Our sample was drawn from the juvenile justice populations in two Ohio counties. Youths were excluded if they had been diverted from juvenile court involvement (approximately 25\% of juvenile court referrals: Snyder and Sickmund, 1999), generally because the offence was minor, the youth a first-time offender or the offence limited to such behaviour as curfew violation. At the other extreme, youths were also excluded if they had been transferred to an adult criminal court 
(about $4.5 \%$ of adjudicated delinquent offenders: Mallett, 2007), because the offense was very serious (murder, aggravated murder) and/or the youth was nearing the age of majority. The youths studied here were young offenders under juvenile court probation supervision.

Both the Lorain and Cuyahoga, Ohio Counties' probation supervision populations were randomly sampled for each year of data collection, using an electronic random number table (Urbaniak and Plous, 2007). The Lorain County Juvenile Court, average 510 youths per year, provided 2 years of data (2005 and 2006) while the Cuyahoga County Juvenile Court, average 3600 youths per year, provided 3 years (2003, 2004 and 2005). Cuyahoga County (City of Cleveland) is categorised as a large urban area and Lorain County a mid-size urban area (Stahl et al., 2007). These two counties are geographically connected in Northeast Ohio.

The final sample was of 555 youths, 306 from Cuyahoga County (102 in each study year) and 249 from Lorain County $(2005, n=124 ; 2006, n=125)$. Most were male $(n=398,71.7 \%)$, most from an ethnic minority $(n=300,54.4 \%$ African-American; $n=215,39.9 \%$ Caucasian; $n=29,5.6 \%$ Hispanic-American; and 11 missing). Age at the time of juvenile court probation supervision ranged from $151(27.3 \%)$ under the age of 14 years, 129 (23.3\%) aged 15, 165 (29.7\%) aged 16 and $110(19.7 \%)$ aged 17.

\section{Data collection}

The Cuyahoga County Juvenile Court in collaboration with the Cuyahoga County Children's Services and the Lorain County Juvenile Court with the Lorain County Children's Services provided copies of anonymised case files for the youths selected, according to ethical requirements as approved by the Institutional Review Board (approval \#27141-MAL-HS and \#26459-MAL-HS). These files included probation supervision case files, juvenile court histories, mental health assessments, psychological assessments, child welfare intake and assessments, and child welfare investigation findings. Inter-rater reliability on the data extraction was high (.95). In most cases, the mental disorder had been assessed and diagnosed prior to the juvenile offending; in other words, in most cases the date of onset of the mental disorder(s) predated the juvenile court delinquency adjudication(s). Diagnoses had been made and documented by a state-licensed clinical professional (psychiatrist, psychologist or counsellor).

\section{Measurements}

The dependent variable was any delinquency adjudication by the juvenile court between the years of 11 and 17. The independent variables were two measures of mental disorder - ADHD and mood disorder - and one of childhood maltreatment. Firstly, ADHD was rated as present or absent according to whether the 
youth had ever been diagnosed with ADHD. Secondly, a mood disorder was rated as present or absent if the youth had ever been diagnosed with major depressive disorder or bipolar type I or II disorder (any 296 code except 296.0 single manic episode, 300.4 and 311; American Psychiatric Association, 2000). While controversy still exists regarding psychiatric diagnostic categories, the standard used in the USA is the Diagnostic and Statistical Manual of Mental Disorders, Fourth Edition; and here, each youth who was measured to have a mental disorder was assessed and diagnosed by a licensed clinician, with specific skills in applying such diagnostic criteria to children and adolescents, using this standardised nosology. Thus, the diagnostic process was reliable and valid. The third principal measure for investigation was the number of maltreatment types each youth had encountered. The theoretical range for this variable was zero (no documented maltreatment history) to three (three different types of maltreatment - physical abuse, sexual abuse and neglect). In addition, a three-category race variable was utilised as a control variable (African-American, Caucasian and Hispanic-American).

\section{Data analysis}

Logistic regression analysis was used to investigate whether the mental health and maltreatment variables were independently associated with later delinquency in this sample, first entering each independent variable separately, and then entering them together. Data were screened for missing data and outliers. A preliminary regression was conducted to calculate Mahalanobis distance and to examine multicollinearity among the predictors. Tolerance for all variables was greater than 0.1, indicating multicollinearity was not a problem. Three outliers were identified and recoded.

\section{Results}

Nearly 16 per cent of the sample had an ADHD diagnosis ( $n=88,15.9 \%)$, and nearly 15 per cent had a diagnosis of depression or bipolar $(n=82,14.8 \%)$. Most of the youths had experienced maltreatment $(n=350,63.0 \%)$. Among those maltreated, 267 children had experienced one type of maltreatment $(48.1 \%$ of full sample), 64 experienced two types of maltreatment (11.7\%), 19 experienced three types of maltreatment (3.5\%) and 10 cases (1.8\%) were missing. A majority of the sample was adjudicated delinquent $(n=430,77.5 \%)$; the others were youths involved with the juvenile court and under probation supervision $(n=120$, 22.5\%), but without the delinquency adjudication.

The model of best fit $\left[X^{2}(d f 5)=53.53, p<0.00\right]$ correctly classified $77 \%$ of cases, and is shown in the Table 1. Prior diagnosis of any kind of depression was associated with six times the likelihood of subsequent delinquency adjudication. 
Table 1: The relationship between antecedent mental disorder or maltreatment and delinquency adjudication in Ohio: regression coefficients indicating independence of relationships

\begin{tabular}{|c|c|c|c|c|c|c|c|c|}
\hline Variable & $\mathrm{B}$ & SE & Wald & df & $p$ & $\begin{array}{l}\text { Odds } \\
\text { ratio }\end{array}$ & $\begin{array}{l}95 \% \text { CI } \\
- \text { lower }\end{array}$ & $\begin{array}{l}95 \% \text { CI } \\
\text { - upper }\end{array}$ \\
\hline $\begin{array}{l}\text { African-American race } \\
\quad \text { (indicator) }\end{array}$ & - & - & - & - & 0.00 & - & - & - \\
\hline Caucasian & -1.71 & 0.24 & 49.89 & 1 & 0.00 & 0.180 & 0.112 & 0.290 \\
\hline Hispanic-American & -1.01 & 0.50 & 4.058 & 1 & 0.04 & 0.363 & 0.135 & 0.973 \\
\hline $\begin{array}{l}\text { Attention-deficit } \\
\text { hyperactivity disorder }\end{array}$ & 0.44 & 0.37 & 1.69 & 1 & 0.19 & 1.55 & 0.801 & 2.99 \\
\hline Depression/Bipolar* & 2.06 & 0.495 & 17.35 & 1 & 0.00 & 7.85 & 2.97 & 20.70 \\
\hline $\begin{array}{l}\text { Number of maltreatment } \\
\text { types* }\end{array}$ & - & - & $\begin{array}{l}27.32 \\
30.27\end{array}$ & 3 & 0.00 & - & & \\
\hline One type of maltreatment & -1.15 & 0.28 & 16.73 & 1 & 0.00 & 0.32 & 0.184 & 0.551 \\
\hline Two types of maltreatment & -1.85 & 0.38 & $\begin{array}{l}23.09 \\
25.58\end{array}$ & 1 & 0.00 & 0.16 & 0.074 & 0.335 \\
\hline Three types of maltreatment & -0.34 & 0.71 & 0.28 & 1 & 0.63 & 0.71 & 0.175 & 2.88 \\
\hline
\end{tabular}

*Indicates variable significant at less than 0.01 .

Number of maltreatment types for youth was also significantly related to delinquency adjudication, here apparently as a protective factor, with youths adjudicated delinquent being three times less likely to have experienced any one form of abuse, and six times less likely to have experienced any two kinds of abuse. There was no relationship with having experienced all three kinds of abuse, but numbers were small in this group. ADHD was not found to be significantly associated with later delinquency.

\section{Discussion}

In a randomly selected cohort, we found that early diagnosis of any kind of depressive disorder was associated with later delinquency adjudication, but ADHD was not. This broadly fits with previous research which has found having a mental health disorder to be predictive of later delinquency (Hawkins et al., 1998; Overbeek et al., 2001), although not with more specific previous findings with respect to ADHD (Tremblay and LeMarquand, 2001). The finding with respect to depression should be treated with caution, because of the very broad concept of depressive disorder applied, but further research of these factors would be warranted. This is supported by a recent review of all detained or incarcerated juvenile offenders in the USA, which indicated that prevalence of depressive disorders 
ranges from 7\% (Shelton, 2001) to 33\% (Timmons-Mitchell et al., 1997), with females more often so diagnosed when this gender differentiation was included (Teplin et al., 2006).

Our study also identified maltreatment as an apparently protective factor. This seems counter-intuitive. Any link between maltreatment and delinquency is, however, complicated (Smith and Thornberry, 1995; Lemmon, 2006). Most previous literature does not measure number of maltreatment types, just whether maltreatment occurred and, sometimes, which type (Smith and Thornberry, 1995; Maxfield and Widom, 1996; Lemmon, 1999; Wiebush et al., 2000; Mersky and Reynolds, 2007). More recently, however, it was found that experiencing multiple forms of maltreatment increased delinquency outcomes (Currie and Tekin, 2006) and that number of maltreatment types were linked to youth adjudication for a violent offense or multiple violent petitions (Mersky and Reynolds, 2007). Important additional information is needed to make sense of these contradictions. It may be that, in Ohio, children who had been maltreated were identified and offered interventions which were at least partially successful; it is known that early identification of abuse or neglect, and subsequent supervision, is one of the more effective strategies to improve at-risk youth outcomes (Nelson and Nash, 2008). The puzzle is that, as the depressive illnesses had all been identified in advance of the delinquency adjudication, nevertheless, they were associated with the poorer outcome. Although interventions for pre-pubertal children with depression have not been fully researched, interventions that are effective with older youth have been identified including cognitive-behavioural therapy, pharmacotherapy, and interpersonal therapy and involvement in positive activities (National Institute of Mental Health, 2004).

Future research should always take account of interventions following a disorder or maltreatment finding. Further, monitoring of such conditions and their progress is essential to ensure that the interventions are being delivered and taken up and producing the desired change.

\section{Limitations}

Our study has some limitations. First, the findings are from youths from only two counties in one state of the USA, so they may not be generalisable. Male youths predominated in the sample (72\%), so the work should be replicated with female teenagers. Variables were chosen for inclusion in this study according to evidence from previous literature, but also data availability. There is a chance that important unselected variables were not utilised. Another possible concern is a large $-2 \log$ likelihood estimate, which could be an indication of model instability; however, here the strongly significant model chi-square and greater than 1 odds ratio findings show a good model fit (Mertler and Vannata, 2005). Finally, we employed secondary data analysis. Although reliability checks were extensive, the extent to which the original data files contained errors is unknown. 


\section{Conclusion}

We have found evidence that a diagnosis of depression in children or adolescents is associated with later delinquency. We found that a history of maltreatment was apparently protective. We speculate that greater awareness of the potential damage from maltreatment may have attracted useful interventions for these young people, and that our findings suggest a new avenue for further help.

\section{References}

American Psychiatric Association (2000) Diagnostic and Statistical Manual of Mental Disorders - IV, text revisions. Washington D.C.: American Psychiatric Association Press.

Bazelon Center for Mental Health (2007) Fact Sheet on Children's Mental Health. http://www. bazelon.org/issues/children/factsheets/index.htm

Benda BB, Tollet CL (1999) A study of recidivism of serious and persistent offenders among adolescents. Journal of Criminal Justice 27: 111-126.

Buka S, Earls F (1993) Early determinants of delinquency and violence. Health Affairs Winter 1993, 46-64.

Burrell S, Warboys L (2000) Special education and the juvenile justice system. Department of Justice, Office of Juvenile Justice and Delinquency Prevention, Department of Justice, Washington DC.

Center for Mental Health Services (2004) Mental Health, United States. U.S. Department of Health and Human Services, Public Health Service, Washington, D.C.

Crooks C, Scott K, Wolfe D, Chiodo D, Killip S (2007) Understanding the link between childhood maltreatment and violent delinquency: what do schools have to do? Child Maltreatment 12: 269-280.

Currie J, Tekin E (2006) Does child abuse cause crime? http://aysps.gsu.edu/publications/2006/ downloads/CurrieTekin_ChildAbuse.pdf.

Davis A, Tsukida C, Marchionna S, Krisberg B (2008) The declining number of youth in custody in the juvenile justice system. National Council on Crime and Delinquency. http://www.nccd-crc. org/nccd/n_initmhjj_pubs.html [18 August 2008].

Egeland B, Tuppett Y, Appleyard K, van Dulmen M (2002) The long-term consequences of maltreatment in the early years: a developmental pathway model to antisocial behavior. Children's Services: Social Policy, Research, and Practice 5: 249-260.

Fagan AA (2005) The relationship between adolescent physical abuse and criminal offending: support for an enduring and generalized cycle of violence. Journal of Family Violence 20: 279-290.

Farrington DP (2005) Origins of violent behavior over the life span. In Flannery DJ, Flannery A, Waldman L (eds) The Cambridge Handbook of Violent Behavior. New York: Cambridge University Press.

Fazel S, Doll H, Langstrom N (2008) Mental disorders among adolescents in juvenile detention and correctional facilities: a systematic review and metaregression analysis of 25 surveys. Journal of the American Academy of Child and Adolescent Psychiatry 47: 1010-1019.

Ford JD, Chapman JF, Hawke J, Albert D (2007) Trauma among youth in the juvenile justice system: critical issues and new directions. National Center for Mental Health and Juvenile Justice. www. ncmhjj.com [15 August 2008].

Gellerman B, Zimerman B, Williams M, Bolhofner K, Craney J (2001) Bipolar disorder at prospective follow-up of adults who had pre-pubertal major depressive disorder. American Journal of Psychiatry 158, 125-127. 
Goldstein N, Olubadewo O, Redding R, Lexcen F (2005) Mental health disorders. In Heilbrum $\mathrm{K}$, Goldstein N, Redding R (eds) Juvenile Delinquency: Prevention, Assessment and Intervention. New York: Oxford University Press.

Grisso T (2008) Adolescent offenders with mental disorders. Future of Children 18: 143-162.

Hawkins JD, Herrenkohl TL, Farrington DP, Brewer D, Catalano RF, Harachi TW (1998) A review of predictors of youth violence. In Loeber R, Farrington DP (eds) Serious and Violent Juvenile Offenders: Risk Factors and Successful Interventions. Thousand Oaks, CA: Sage Publications pp. 106-146.

Heilbrun K, Goldstein N, Redding R (2005) Juvenile Delinquency: Prevention, Assessment, and Intervention. New York: Oxford University Press.

Holman B, Ziedenberg J (2006) The Dangers of Detention: The Impact of Incarcerating Youth in Detention and Other Secure Congregate Facilities. Baltimore, MD: Annie E. Casey Foundation.

Howing PT, Wodarski JS, Kurtz PD, Gaudin, JM, Herbst EM (1990) Child abuse and delinquency: the empirical and theoretical links. Social Work 35: 244-249.

Huizinga D, Loeber R, Thornberry TP, Cothern L (2000) Co-occurrence of Delinquency and Other Problem Behaviors. Juvenile Justice Bulletin. Department of Justice, Washington, DC.

Kashani J, Jones M, Bumby K, Thomas L (1999) Youth violence: psychosocial risk factors, treatment, prevention, and recommendations. Journal of Emotional and Behavioral Disorders 7: 200-212.

Lay B, Ihle W, Esser G, Schmidt MH (2005) Juvenile-episodic, continued or adult-onset delinquent?: risk conditions analyzed in a cohort of children followed up to age of 25 years. European Journal of Criminology 2: 39-66.

Lemmon JH (1999) How child maltreatment affects dimensions of juvenile delinquency in a cohort of low-income urban males. Justice Quarterly 16: 357-376.

Lemmon JH (2006) The effects of maltreatment recurrence and child welfare on dimensions of delinquency. Criminal Justice Review 31: 5-32.

Lexcon F, Redding RE (2000) Mental health needs of juvenile offenders. Juvenile Correctional Mental Health Report 3: 2, 8-16.

Loeber R, Farrington DP (2001) The significance of child delinquency. In Loeber R, Farrington DP (eds) Child Delinquents: Development, Intervention, and Service needs. Thousand Oaks CA: Sage Publications pp. 1-22.

Loeber R, Kenan, K (1994) Interaction between conduct disorder and its comorbid conditions: effects of age and gender. Clinical Psychology Review 14: 497-523.

Lyons J, Shafer K (2000) Mental health and dangerousness: characteristics and outcomes of children and adolescents in residential placement. Journal of Child and Family Studies 9: 67-73.

Maas C, Herrenkohl TI, Sousa C (2008) Review of research on child maltreatment and violence in youth. Trauma, Violence, $\mathcal{E}$ Abuse 9: 56-67.

Mallett C (2007) Death is not different: the transfer of juvenile offenders to adult criminal courts. Criminal Law Bulletin 43: 523-547.

Mallett C (2008) The disconnect between delinquent youths with mental health and special education disabilities and juvenile court outcomes. Correctional Health Today 1: 12-21.

Maxfield JG, Widom CS (1996) The cycle of violence: revisited six years later. Archives of Pediatric and Adolescent Medicine 150: 390-395.

Mears D, Aron L (2003) Addressing the Needs of Youth with Disabilities in the Juvenile Justice System: The Current State of Knowledge. Washington, DC: Urban Institute, Justice Policy Center.

Mersky JP, Reynolds AJ (2007) Child maltreatment and violent delinquency: disentangling main effects and subgroup effects. Child Maltreatment 12: 246-258.

Mertler CA, Vannata RA (2005) Advanced and Multivariate Statistical Methods (3rd Ed.). Glendale, CA: Pryzak Publishing. 
Moffitt T, Scott S (2008) Conduct disorders of childhood \& adolescence (Chapter 35). In Rutter M (ed) Child Psychiatry. London: Wiley-Blackwell Publishers.

Moffitt TE (1993) Adolescence-limited and life-course persistent antisocial behavior: a developmental taxonomy. Psychological Reviews 100: 674-701.

National Institute of Mental Health (2004) Prevention of depression in children and adolescents. http://www.nimh.nih.gov/research-funding/scientific-meetings/2004/workshop-on-theprevention-of-depression-in-children-and-adolescents/summary-shtml [19 August 2008].

National Institute of Mental Health (2006) Benefits, limitations, and research needs in treating youth with depression. http://www.nimh.nih.gov/research-funding/scientific-meetings/2006/benefitslimitations-and-emerging-research-needs-in-treating-youth-with-depression/summary.shtml [19 August 2008].

National Institute of Mental Health (2007) Rates of bipolar diagnosis in youth rapidly climbing, treatment patterns similar to adults. http:/www.nimh.nih.gov/science-news/2007/rates-ofbipolar-diagnosis-in-youth-rapidly-climbing-treatment-patterns-similar-to-adults.shtml $\quad[19$ August 2008].

Nelson KE, Nash JK (2008) The effectiveness of aftercare services for African American families in an intensive family preservation program. Research on Social Work Practice 18: 189-197.

New Freedom Commission on Mental Health (2003) Achieving the promise: Transforming mental health care in America, Final Report, p. 2, Rockville, MD, DHHS \#SMA-03-3832. http://www. mentalhealthcommission.gov/reports/reports/htm [19 August 2008].

Office of Juvenile Justice and Delinquency Prevention (2003). Census of juveniles in residential placement databook: Washingtion DC. http://ojjdp.ncjrs.org/ojstatbb/cjrp/asp/State_ Adj.asp.

Overbeek G, Vollebergh W, Meeus W, Engels R, Luijpers E (2001) Course, co-occurrence, and longitudinal associations of emotional disturbance and delinquency from adolescence to young adulthood: a six year three wave study. Journal of Youth and Adolescence 30: 401-426.

Poe-Yamagata E, Jones M (2000). And justice for some. Building Blocks for Youth, Washington DC. http://www.buildingblocksforyouth.org/justiceforsome/ [28 August 2008].

Preski S, Shelton D (2001) The role of contextual, child, and parent factors in predicting criminal outcomes in adolescence. Issues in Mental Health Nursing 22: 197-205.

Roberts AR (2004) Juvenile Justice Sourcebook: Past, Present, and Future. New York: Oxford Press.

Shader M (2003) Risk factors for delinquency: An overview. Office of Juvenile Justice and Delinquency Prevention. http://www.ncjrs.gov/html/ojjdp/jjjournal_2003_2/index.html [18 August 2008].

Shelton D (2001) Emotional disorders in young offenders. Journal of Nursing Scholarship 33: 259-263.

Sickmund M, Sladky TJ, Kang W (2004) Census of juveniles in residential placement databook. http://www.ojjdp.ncjrs.org/ojstatbb/cjrp/ [25 August 2008].

Simpson B, Bloom B, Cohen R, Blumberg S, Boudeon, KH (2005) U.S. children with emotional and behavioral difficulties: Data from the 2001, 2002, and 2003 National Health Interview Surveys. Advance data from Vital and Health Services, Number 360. Hyattsville, MD: National Center for Health Studies, DHHS \#2005-1250. http:/www.cdc.gov/nchs/data/ad/ad360.pdf.

Smith C, Thornberry TP (1995) The relationship between childhood maltreatment and adolescent involvement in delinquency. Criminology 33: 451-481.

Snyder HN, Sickmund M (1999) Juvenile offenders and victims: 2002 national reports. Washington D.C: U.S. Department of Justice.

Stahl AL (2006) Delinquency cases in juvenile court, 2002, U.S. Department of Justice, Office of Juvenile Justice and Delinquency Prevention, Washington DC. http://www.ncjrs.gov/pdffiles1/ ojjdp/fs200602.pdf [25 August 2008]. 
Stahl AL, Puzzanchera C, Livesey S, Sladky A, Finnegan T, Tierney N, Snyder H (2007). Juvenile court statistics, 2003-2004. National Center for Juvenile Justice, OJJDP. http://www.ncjrs.gov/ html/ojjdp/218587/ [25 August 2008].

Substance Abuse and Mental Health Services Administration, Office of Applied Statistics (2004) Results from the 2004 National Survey on Drug Use and Health. http://www.oas.samhsa.gov/ nsduh/2k4nsduh/2krResults/2k4Results.htm [24 August 2008].

Takeda Y (2000) Aggression in relation to childhood depression: a study of Japanese 3rd-6th graders. Japanese Journal of Developmental Psychology 11: 1-11.

Teplin L, Abram K, McClelland G, Dulcan M, Mericle A (2002) Psychiatric disorders in youth in juvenile detention. Archives of General Psychiatry 59: 1133-1143.

Teplin L, Abram K, McClelland G, Mericle A, Dulcan M, Washburn D (April 2006) Psychiatric disorders of youth in detention. Office of Juvenile Justice and Delinquency Prevention, Juvenile Justice Bulletin, Office of Justice Programs, Washington DC. http://www.ncjrs.gov/pdffiles1/ ojjdp/210331.pdf [25 August 2008].

Timmons-Mitchell J, Brown C, Schulz SC, Webster SE, Underwood LA, Semple W (1997) Comparing the mental health needs of female and male incarcerated juvenile delinquents. Behavior Sciences and the Law 15: 195-202.

Torres C, Ooyen MV (2002) Briefing paper, Committee on Youth Services. http://webdocs. nyccouncil.info/attachments/56612.htm?CFID $=1677675 \& C F T O K E N=84562487$ [28 August 2008].

Tremblay RE, LeMarquand D (2001) Individual risk and protective factors. In Loeber R, Farrington DP (eds) Child Delinquents: Development, Intervention, and Service Needs. Thousand Oaks, CA: Sage Publications pp. 137-164.

Turner M, Hartman J, Exum M, Cullen F (2007) Examining the cumulative effects of protective factors: resiliency among a national sample of high-risk youths. Journal of Offender Rehabilitation 46: 81-111.

U.S. Department of Education, Office of Special Education Programs (2001) Twenty-third Annual Report to Congress on the Implementation of the IDEA: Results.

Urbaniak GC, Plous S (2007) Research randomizer. Social Psychology Network. http://www. randomizer.org/form.htm [28 August 2008].

Wasserman GA, McReynolds LS, Lucas CP, Fisher P, Santos L (2002) The voice DISC-IV with incarcerated male youths: prevalence of disorder. Journal of the American Academy of Child and Adolescent Psychiatry 41: 314-321.

Weiss B, Garber J (2003) Developmental differences in the phenomenology of depression. Development and Psychopathology 15: 403-430.

Wiebush R, McNulty B, Le T (2000) Implementation of the intensive community-based aftercare program. Bulletin, Department of Justice. Washington D.C.: OJJDP.

Widom CS (1991) The role of placement experiences in mediating the criminal consequences of early childhood victimization, American Journal of Orthopsychiatry 61: 195-209.

Widom CS, Maxfield MG (2001) Research in brief: An update on the "cycle of violence". U.S. Department of Justice, Office of Justice Programs, National Institute of Justice, Washington D.C.

World Health Organization (2005) Mental health of children and adolescents. WHO European Ministerial Conference on Mental Health, Helsinki, Finland, February 12-15, 2005.

Post-print standardized by MSL Academic Endeavors, the imprint of the Michael Schwartz Library at Cleveland State University, 2014 